DOI: $10.26565 / 2312-5675-2021-17-05$

UDC 616.83-06[616.98:578.834COVID-19

\title{
REVIEW OF THE PATHOGENESIS, CLINICAL MANIFESTATIONS AND PECULIARITIES OF NEUROPSYCHIC DISORDERS CAUSED BY COVID-19
}

\author{
0. Merkulova, Said S. Nassr
}

\section{Olga Yu. Merkulova}

\author{
*V. N. Karazin Kharkiv National University; Svobody Square, 6, 61022, Kharkiv, Ukraine \\ o.merkulova@karazin.ua \\ ORCID ID: 0000-0001-6880-0360
}

nassrsaid5@gmail.com

ORCID ID: 0000-0001-8553-4332

The article presents literature data numerous studies of patients with COVID-19. The available information helps to explain the nature and structure of the virus, the ways of penetration and its distribution in the human body, its interaction with the immune, nervous, endocrine, vascular, muscular systems, as well as the pathogenesis, clinic, diagnosis and treatment of this contingent of patients. Due to tropisms SARS-COV-2 to the human cells specific $S$ glycoprotein this virus can bind receptor human angiotensin-converting enzyme 2 (ACE-2), fuse with host cells and disseminate in the organism. Renin-angiotensin-aldosteron system (RAAS) plays an important role in regulation of blood vessels, heart, kidneys functions. ACE-2 has an influence on the inflammatory, fibrotic and immunomodulatory mechanisms. Inhibition of these protection functions due to spread SARS-COV-2 in human body leads to the progression of cardiovascular, renal and pulmonary diseases. Some authors describe indirectly the viral entry into the brain parenchyma by infecting the T-lymphocytes, that usually is accompanied by inflammatory reactions with an increase in the specific cytokines such as interleukins (IL) - 6, IL-8, tumor necrosis factor, monocyte chemoattractant protein-1 (MCP-1). The peculiarities of the binding of the virus to the human cells are the presence of neurotropic properties and the ability to change the permeability of blood brain barier (BBB). Other authors note that the virus crosses the BBB directly through the olfactory neurons and also the brain's circumventricular organs structures, surrounding the third and fourth ventricles, and promote the infection of nervous system. It can also cause intravascular coagulation and blood clotting, which may lead to various diseases of the nervous system. In this regard, an important task for neurologists is to further study the effect of the COVID-19 virus on the nervous system and prevent the occurrence of its complications.

Keywords: COVID-19, SARS-CoV-2, inflammatory mediators, viral glycoproteins, encephalitis.

Як цитувати: Меркулова 0. Ю., Насср С. Cаїд. Review of the pathogenesis, clinical manifestations and peculiarities of neuropsychic disorders caused by COVID-19 // Психіатрія, неврологія та медична психологія. - 2021. - №17. - C. 34-43. https://doi.org/10.26565/2312-5675-2021-17-05

In cites: Merkulova 0. Yu., Nassr S. Said. Review of the pathogenesis, clinical manifestations and peculiarities of neuropsychic disorders caused by COVID-19. Psychiatry, Neurology and Medical Psychology. 2021. № 17, pp. 34-43. https://doi.org/10.26565/2312-5675-2021-17-05 
Introduction. It had been one year and a few months that the world had been struggling with the emergent SARS-CoV-2 infection, which had spread with a very strong agility to reach almost every corner of the globe in just few months. The infection had started from an endemic affecting the city of Wuhan in China where the initial cases of coronavirus infection were identified [1] to a pandemic affecting nearly all the nations of the earth. The fear that is associated with this virus had not come from absolute nothingness; it is due to the severity of the pulmonary manifestation that was resulted from this infection and the wide range of systemic illnesses that can result out of it. The disease, later called COVID-19, is caused by the SARS-CoV-2 virus [2]. Coronavirus is within the genus of betacoronavirus which is from the Coronaviridae family [3], these are enveloped viruses and they have no-segmented and singlestranded RNA genome [2]. SARS-CoV-2 gets transmitted from one person to the other through direct contact or when droplets that are sneezed or coughed up are caught up on the recipient's mucosa [4]. The main reason behind the wide spreading of the disease is that the carriers of the disease can remain asymptomatic for a long period of time while still getting in contact with others [5]. That is why the control of this virus in spreading is very to monitoring.

Pathogenesis. Like other coronaviruses, this virus uses spike glycoproteins that help and allow this virus to bind the surface receptors of our own body cells, ensuring its access into them. This specificity in binding between the glycoproteins and the receptors on specific cells is known as tropisms. These viral glycoproteins that are expressed in the surface of these viruses are known as the $S$ glycoproteins. The $S$ glycoprotein, comprises two functional subunits: the S1 subunit, which binds to the host cell receptor, and the S2 subunit, which catalyzes the fusion of viral and cellular membranes. The receptor-binding domain (RBD) which part of $S 1$ subunit binds to a peptidase domain which is found in the human angiotensin-converting enzyme 2 (ACE-2) $[6 ; 7]$ after the cleavage takes place, the $\$ 2$ domain gets exposed and this allows its binding with the fusion peptide and another factor like the internal fusion peptide. At this stage the virus gets to fuse with the cell membrane (figure 1) [8].

Thus, the ACE-2-RBD binding affinity determines the person's susceptibility to get infected with the SARS-CoV-2 virus. SARS-CoV-2 has shown neurotropic features and the capacity to result in various neurological disorders. It had been shown that SARS-CoV-2 was present in the cerebrospinal fluid (CSF) of many patients who had been infected with SARS-CoV-2 [9]. Although it had been proven that it has a role in the regulation of the blood pressure, now it is as well evident that the activity of the ACE-1 / Angiotensin-2 (Ang-II) pathway contributes to other important physiological processes. Many studies have shown that this system is vastly present in various organ systems, and it was found to be associated proinflammatory, and it can induce proliferation and fibrosis in the affected organ [4-5; 10-11]. As it is now known, there is an additional factor in the RAAS, which is the corresponding homolog of ACE-1. This homolog is the wellknown ACE-2, which is able to cleave Ang-II and it in turn converts it from angiotensin (1-9) to angiotensin (1-7). This permits the decrease in the fibrotic and the proliferative role of angiotensin $2[5 ; 10-11]$. Due to this, we can expect that this additional ACE- 2 arm of the RAAS system can be possibly impaired or inactive, which makes it a contributory factor in many cardiovascular diseases and other systemic diseases in relation to inflammation [5]. ACE-2 mechanism of action was also seen in models of diseases like obesity, cerebral ischemia, atherosclerosis, and others by causing the reduction in cytokine production and interfering with fibrotic signaling pathways [11]. This can exacerbate inflammatory symptoms in SARS-CoV-2 infected patients. The binding of SARS-CoV-2 to ACE-2 also lessens its

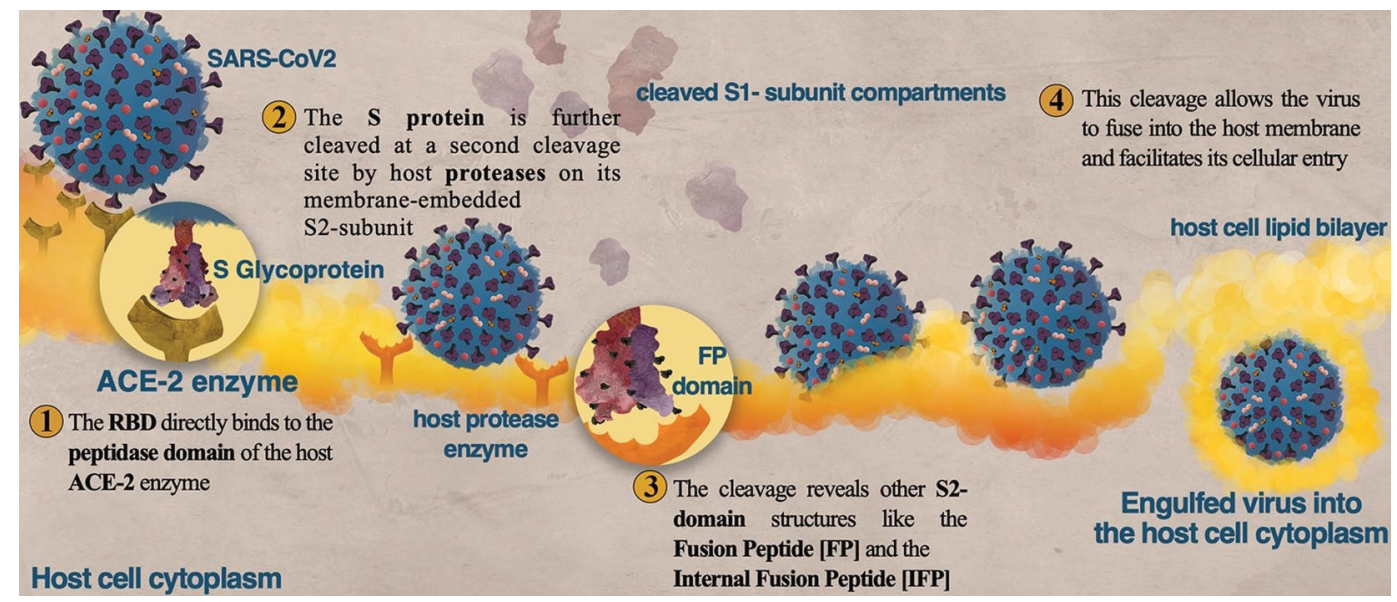

Fig. 1. The potential role of ACE-2 in SARS-COV2 host cell entry mechanism [5] 
availability to cleave Ang-II, extending its vasoconstrictive and pro-inflammatory roles [12].

Evaluation of immune response childrens with CNS encephalitis-like infection and respiratory tract infection due to COVID-19 indicate on significantly higher level of cytokines such as granulocyte macrophage colonystimulating factor (GM-CSF), IL-6, IL-8, MCP-1, and GM-CSF in their CSF compared to serum samples. These characteristics of cytokine level may be prognostic factor in disease progression [13].

As known ACE- 2 is expressed in such tissues as alveolar cells of lung, gastrointestinal tract (GIT) and brain [14]. As well as symptoms lesion of respiratory system and GIT we meet with COVID-19-associated acute cerebrovascular system (CVS) diseases such as ischemic and hemorrhagic stroke, thrombosis of cerebral venous sinuses, inflammatory coagulopathy. This conditions often connected with development seriously complications, increase level of cytokines and development inflammatory cytokine storm [14]. SARS-CoV-2 infection causes disseminated intravascular coagulation and diffuse clots in the blood. In addition to that the close adherence between the endothelial cells of the blood vessels gets interrupted, which in turn increases the BBB permeability leading to lesions in the CNS. This causes small lesions within the CNS, which allows SARS-CoV-2 to enter into the CNS. Coherent with viral brain infections, COVID-19-caused encephalitis can stem from systemic inflammation and disturbance of the $B B B$ and results in seizures and acute hemorrhagic necrotizing encephalopathy, that is a rare complication of viral infections. Also, regulation of coagulation, blood clotting, and BBB permeability engages pro-inflammatory cytokines, such as interferon- $\gamma$, and inflammatory mediators such as arachidonic acid derivatives (figure 2) [4;5].

Clinic. Essential and common neurological symptoms including gustatory and olfactory dysfunctions, myalgia, headache, altered mental status, confusion, delirium, and dizziness. Moreover, neurological manifestations and complications that are of great concern such as stroke, seizures, cerebral (sinus) venous thrombosis, meningoencephalitis, Guillain-Barré syndrome, acute myelitis, and posterior reversible encephalopathy syndrome are also tackled systematically [14].

In a Beijing Hospital, Chinese, the virus COVID-19 was detected in the CSF of the 56-year old man who was later diagnosed with encephalitis. His consciousness decreased, but his computer tomography did not revealed a brain pathology. His neurological symptoms gradually regressed after treatment [15].

Many emerging reports now had highlighted the ability of the SARS-CoV-2 virus to infect the central nervous system and cause many of its noticed and prevalent neurological disorders.

The first case of the 24-year old man of COVID-19 meningitis/encephalitis was noted in Japan in whose CSF RNA for theSARS-CoV-2 was detected, but in nasopharengeal swab virus was negative. The patient presented with fever, headache, and generalized fatigue, convulsions with subsequent unconsciousness and neck stiffness. Artifitial ventilations of lungs was made due to multiple epileptic seizures. His Glasgow Coma Scale was 6. CT-chest shows bilateral pneumonia with small zones of lesion.

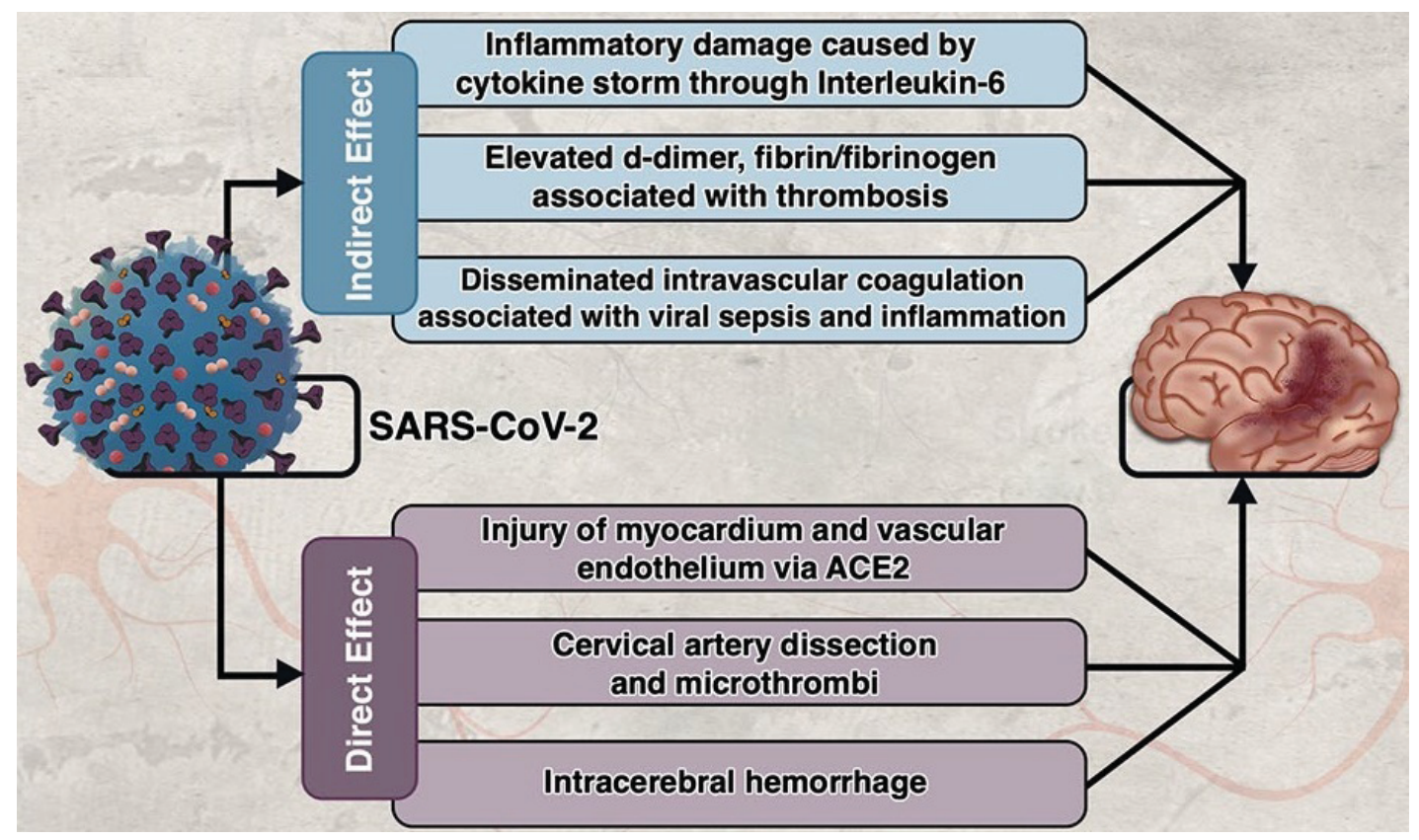

Fig. 2. Direct and indirect effects of SARS-COV2 on the brain [5] 
On MRI investigation, his right temporal lobe and hippocampus showed hyper-intense signal changes with minor hippocampal atrophy, which indicated right lateral ventriculitis and encephalitis [9]. Thus symptoms of lesion NS as encephalitis or meningitidis may be the first as well as respiratory system involvement due to hidden COVID-19 virus.

High risk of development and progression neurological disorder has people 60 years and older with comorbidity pathology as heart and lung disease, diabetes. People with neurologic pathology such as multiple sclerosis, amyotrophic lateral sclerosis, myasthenia gravis, Parkinson's and Alzheimer's disease should be follow recommendations from the Centers for Disease Control and Prevention. Neurologist should be vigilant for the influence COVID-19 on the patients, especially in the case of multiple sclerosis patients, taking immune-modulating therapies. Also patients should avoid the situations connected with high risk of disease [16].

Moreover, patients had been shown to suffer from delirium and agitation [17], as well as in another study there were noted cases of patients who had suffered from necrotizing hemorrhagic encephalopathy [18]. Other report had shown that approximately $33 \%$ of SARS-CoV2-infected patients in three COVID-19-specified hospitals in Wuhan, had displayed a varying degree of neurological manifestations starting from dizziness and altered consciousness and eventually ending up in various severe neurological diseases [18].

In the report by Poyiadji et al. [18] presented the 58year old woman from the USA with fever, cough, and altered mental state where MRI revealed acute necrotizing encephalitis in the bilateral thalami, medial temporal lobes, and sub-insular regions. However as noted in many published articles [9; 13-14], the virus itself was not detected and isolated in the nasopharyngeal swabs of many of the patients. This indicates either the possibility of a faulty swab isolation or the late neurological affection that had emerged after the patient had cleared off the virus and it is not anymore detectable.

Moreover, $37 \%$ of 214 patients who were infected with the SARS-CoV-2 virus had eventually displayed neurological symptoms of some sort. Some people who contract the SARS-CoV-2 infection are prone to developing a transient or a prolonged loss of taste and smell depending on the degree of the inflammatory response that preceded [19; 24]. Furthermore, 125 patients have been described in the national report from the UK that monitored COVID-19 progression. 77 of them prevalence cerebrovascular pathology, of whom $74 \%$ had an ischaemic stroke, $12 \%$ an intracerebral haemorrhage, and 1\% CNS vasculitis. 39 of 125 patients revealed with different alterations mental status, including 7 patients with encephalitis. 10 patiens had primary development psychosis. This information indicated on relations between COVID-19 viral infection and change neurological or neuropsychiatric presentations [20].

Hereby, we can deduce in such a case that the neurological symptoms arising from this infection are quite wide and diverse. It had been further noted by Boehme A. K. et al. [21] that COVID-19 increase the risk of strokes, as well as, many of COVID-19 patients had displayed a wide array of vascular-related diseases such as disseminated pulmonary microthrombi, venous thromboembolism and brain micro strokes [14; 21].

In addition, the psychosocial aspect of the SARS-CoV-2 pandemic can not be ignored. Besides that, survivors exhibited posttraumatic stress disorder (54.5\%), depression (39\%), pain disorder (36.4\%), panic disorder (32.5\%), and obsessive-compulsive disorder (15.6\%) at 31 to 50 months post-infection [22]. Some authors note that delirium and septic encephalopathy vore typical for severly ill patients, smell disorder and headache more common in mild cases [23; 24]. Investigation of 42 patients with pathology NS through 3-4 monthes after COVID-19 revealed that in 95.2\% cases present neurocognitive disorders of different stage [25].

The virus influences on release cytokine IL-6, cause inflammatory damage of tissue as cytokine storm that associated with increase blood viscosity, elevation of D-dimer level, intravascular coagulation and development of stroke $[4 ; 5 ; 13]$. The frequency of ischemic stroke is rare than other pathology NS and some authors indicate $1.1-2.5 \%$ [26-27].

Patients with additional pathology CVS, endocrine, kidney disease have more factors of risk development acute vascular pathology. In articles [23-24] describe the clinical case of minor stroke SARS-Cov-2 positive patient with comorbid pathology as hypertension, type 2 diabetes, chronic renal disease, dyslipidemia and ischemic heart disease with a myocardial infarction. He is 70 years old and smoking. The day before he entered to the hospital with COVID-19-related bilateral pneumonia. Next day developed transitory sensory and motor disturbances on the left side of the body (about 6 hours). He had an implantable cardioverter-defibrillator and pacemaker. Brain CT and angio-CT revealed a thrombus in the right cerebral posterior artery (figure 3).

During neurological examination the disturbances were resolved and neurological status return back to the normal with standard conservative treatment. 


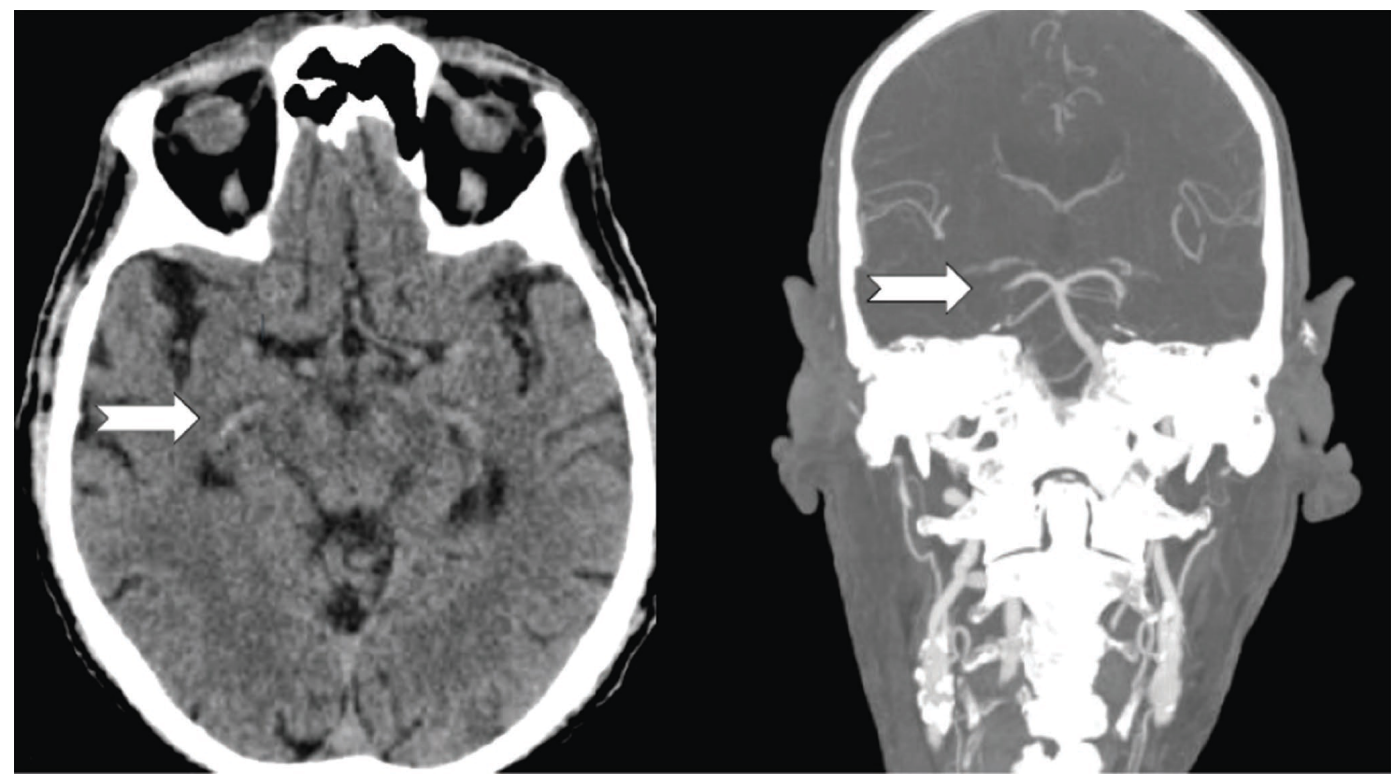

Fig. 3. Brain CT (left) and angio-CT (right) revealed a thrombus in the right cerebral posterior artery (arrows) [23-24] patient with minor stroke.
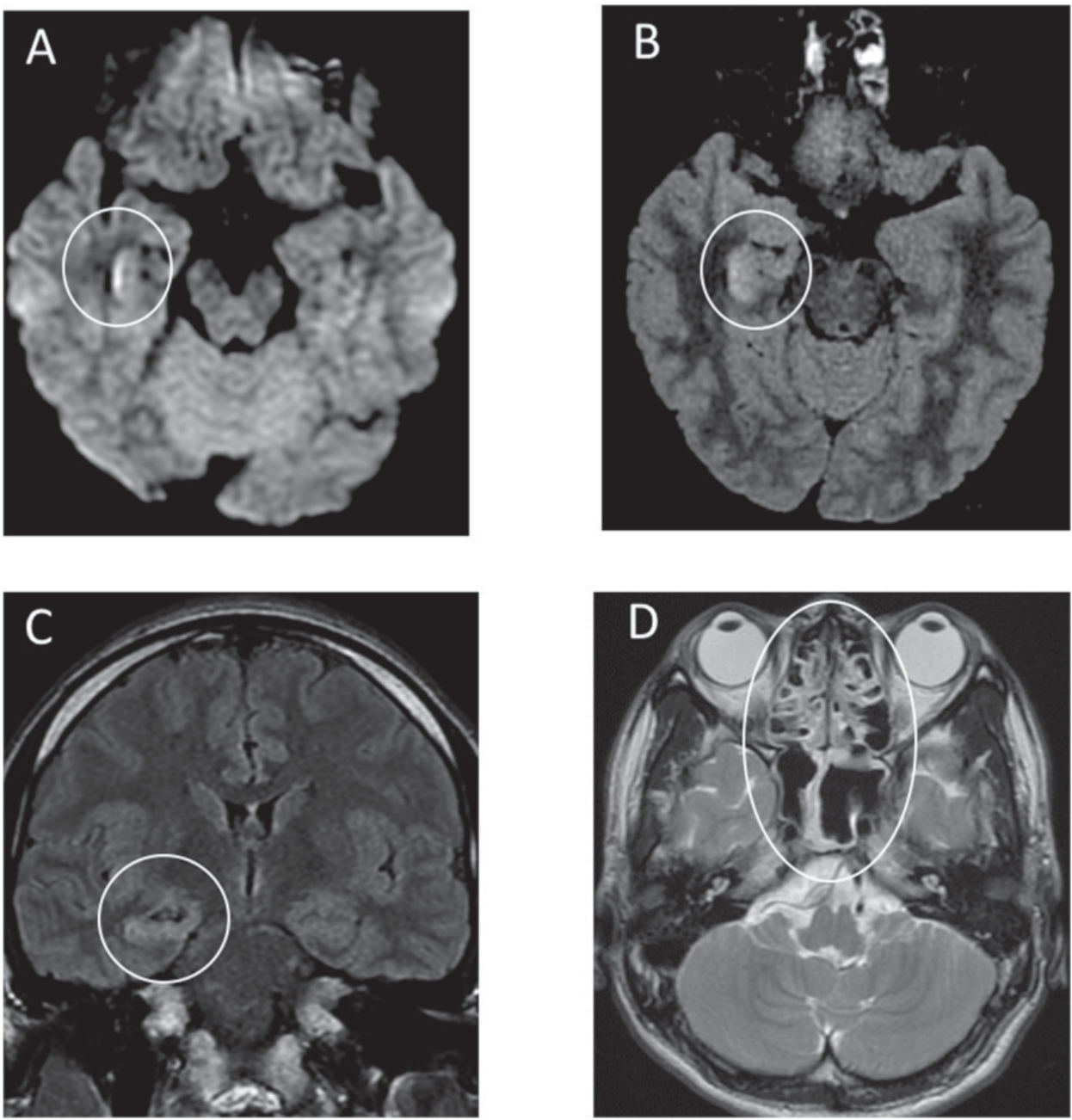

Fig. 4. Brain MRI in 20 hours after admission to the clinic: (A) diffusion weighted images regime revealed zone hyperintensity up the wall right lateral ventricle on the level inferior horn; $(B, C)$ fluid-attenuated inversion recovery images displayed hyperintensive character of alteration of right mesial temporal lobe and hippocampus with mild atrophy of hippocamp; these changings denote on right lateral ventriculitis and encephalitis mostly on right mesial lobe and hippocampus; (D) T2-weighted image displayed pan-paranasal sinusitis [9]. 
So, brain CT angiography is a great tool to detect thrombosis in blood vessels as is the case in a patient who had experienced deterioration in the neurological status after the infection with SARS-COV-2.

Diagnostics. If we suspect that the CNS disease is a complication of COVID-19, CSF extraction and its subsequent analysis within the window period can show elevated levels of the viral RNA. Typically, we can note an increase in the lymphocytes and an additional surge in the proteins levels to more than $2000 \mathrm{pg} / \mathrm{ml}$, which exceeds the normal by $1500 \mathrm{pg} / \mathrm{ml}$ [23]. Even so, it is not obligatory to find the RNA of SARS-CoV-2 in the CSF in all cases because some of the cases of encephalitis are indirectly caused due to the overall immune response against the virus that is not necessarily present in the CNS all the time. Moreover, especially if the patient is still experiencing general suspicious symptoms the real time-polymerase chain reaction assay from the nasopharyngeal swabs needs to be done in order to confirm that the patient had contracted the virus and that it is what is causing the person the systemic illness. However, when the patient displays specific neurological symptoms we need to use more specific and advanced techniques that can highlight the specific changes at the level of the CNS. New conducted researches are highlighting the role of fluorodeoxyglucose-positron emission tomographyscans (FDG-PET-scans) and CT-scans in the analysis of the affection of the nervous tissue by the inflammatory process against the virus. Cognitive performances can be check and assessed using validated screening modalities that depend on the attentional abilities of the patients: Mini-Mental State Evaluation, Frontal Assessment Battery, praxis abilities. So, in patients who had seizures K-spindles can be detected on the electroencephalogram as well as on FDG-PETscans showing hot spots, which indicate hypermetabolic foci [24]. Most of the imaging outcomes of the FDG-PETscan around the 19th-23rd days of the viral infections show bilateral prefrontal and left-sided parieto-temporal hypometabolism and a slight hypermetabolism within the cerebellar vermis [23]. This clinical finding on the FDGPET-scan is now a confluent finding consistent with most of COVID-19 patients displaying cognitive impairments. On later days of the infectious process (after a month and 10 days), FDG-PET-scans suggest different findings specifically hypometabolism within the bilateral prefrontal and associative posterior cortices, and hypermetabolism within the cerebellar vermis [23]. Brain FDG-PET imaging should be considered in patients with Covid-19 presenting with acute central nervous system impairment. Further studies with longitudinal FDG-PET imaging will be important to determine the pathophysiological bases of the pattern of cortical hypometabolism and cerebellar hypermetabolism, and whether these abnormalities are due to functional inactivation rather than irreversible brain damage [23].

MRI images had been found to show hypodense foci in the temporal lobe, hippocampus and the lateral ventricles (figure 4), however, these findings do not seem to be so specific in diagnosing encephalitis specific to COVID-19 [24].

Treatment. Of a great significance while treating patients who have a severe systemic illness secondary to COVID-19, is to initiate the earliest possible and antiinflammatory therapeutic to try and get the inflammatory cytokines under control in order to inhibit the damage that is imparted on the CNS by the cytokines storm. This anti-inflammatory therapy can be delivered through the use of corticosteroids. The importance of pulse therapy with corticosteroids was noted in the article by Delorme C. et al. [23], in which the administration of $2 \mathrm{mg} / \mathrm{kg} /$ day of corticosteroids for 3 days and then $1 \mathrm{mg} / \mathrm{kg} /$ day for 3 days had widely alleviated the symptoms within few days. For the treatment of seizures, the specific anti-epileptic regimen needs to be specific to the type of seizure that the patient has. When treating epilepsy in a given patient with SARS-CoV-2 infection, it is important to check the pharmacological interactions between antiepileptic drugs and the drugs used to treat COVID-19 in that subject.

The clinical case of the 24-year old patient [9] with meningoencephalitis, pneumonia and multiple epileptic seizures discribed earlier shows successful treatment including antibiotics (ceftriaxone, vancomycin), antiviral (acyclovir, then favipiravir) medicine, steroids and anticonvulsant (levetiracetam).

In addition, for the treatment of headaches the usage of non-steroidal anti-inflammatory drugs (NSAIDs) can be given with a careful attention the history of present diseases, especially peptic ulcers, liver diseases, or kidney diseases, as well as any possible hypersensitivity reactions to NSAIDs as well as gabapentin nightly (300 to 900 milligrams) has looked helpful for these patients who have post-COVID-19 lingering headache. Also, in the case of strokes prophylaxis, may include the using of antihypertensive drugs, anticoagulants, platelet antiaggregants, heparin can be used in order to prevent blood clotting and the possibility of ischemic brain injuries. Last but not least, the need for vaccination is essential, which ensures that in case the patient gets sick, they will not get to the point where they require hospitalization and where an aggressive therapeutic regimen needs to be taken to treat the neurological manifestations and to alleviate the neurological symptoms. The exact treatment protocol of the neurological manifestations in COVID-19 is still very flexible 
and it is prone to modifications in the upcoming future due to appear new knowledge about this illness.

COVID-19 Treatment Guidline (April 21, 2021) uses for medical control of mature patients. It bases on the disease severity. So, outpatients with mild to moderate course COVID-19 without at high risk progression this guideline recommends supportive care and symptomatic treatment. All measures should be directed to reduce the risk of virus transmission to others. In the case of high risk of an attack of disease Food and Drug Administration (FDA) recommends to use monoclonal antibodies such as bamlanivimab and etesevimab or casirivimab and imdevimab [28-29]. Antiviral drug remdesivir recommends for the treatment of COVID-19 by FDA too. This schema of treatment is used for in-patients who require additional oxygen [30-33]. Dexamethasone is recommended to improve survival in hospitalized patients who require oxygen support and artifitial ventilation [34-37]. Addiitional assignment of tocilizumab, monoclonal antibody, to dexamethasone therapy usually use to get better survival of the patients with quick respiratory decompensation [38-39].
Conclusion. The neurological manifestations of COVID-19 are of a vast range and research is still ongoing to ensure a full understanding of all the possible pathways that can lead to the development of the various neurological symptoms. The neurological and psychological manifestations of COVID-19 are enormous mainly evolving due to the role of cytokines in targeting the $B B B$, and the subsequent activation of microglia and astrocytes resulting in the degeneration of the neuronal parenchyma. Research for more deliberate mechanisms of the various pathologies needs to expand in order to prevent the severe neuropsychological outcomes of SARS-CoV-2 infection such as stroke, encephalopathy, neuropathy, asthenic syndrome, taste and smell dysfunction and other.

Declaration of Conflicting Interests. The authors declared no potential conflicts of interest with respect to the research, authorship, and/or publication of this article.

\section{ЛІТЕРАТУРА}

1. Structure analysis of the receptor binding of 2019-nCoV / Chen Y., Guo Y., Pan Y. та ін.]. // Biochem Biophys Res Commun. - 2020. - №525. - C. 135-140.

https://www.doi.org/10.1016/j.bbrc.2020.02.071

2. A pneumonia outbreak associated with a new coronavirus of probable bat origin. / Zhou P., Yang X. L., Wang X. G. та iн.]. // Nature. - 2020. - №579. - C. 270-273. https://www.doi.org/10.1038/s41586-020-2012-7

3. Coronaviridae Study Group of the International Committee on Taxonomy of Viruses 2020; Weiss and Navas-Martin 2005

4. Rothan H. A. The epidemiology and pathogenesis of coronavirus disease (COVID-19) outbreak / Rothan H. A., Byrareddy S. N. // J Autoimmun. - 2020. №109. - C. 102433.

https://www.doi.org/10.1016/j.jaut.2020.102433

5. Neurological and neuropsychological changes associated with SARS-CoV-2 infection: new observation, new mechanisms. Review / Haidar A., Jourdi H., Haj Hassan Z та ін.]. // The Neuroscientist. - 2021. - C. 20.

https://www.doi.org/10.1177/1073858420984106

6. The spike glycoprotein of the new coronavirus 2019-nCoV contains a furin-like cleavage site absent in CoV of the same clade. / Coutard B., Valle C., de Lamballerie X. та ін.]. // Antiviral Research. - 2020. - №176. - C. 104742.

https://www.doi.org/10.1016/j.antiviral.2020.104742

7. The coronavirus spike protein is a class I virus fusion protein: structural and functional characterization of the fusion core complex. / Bosch B. J., van der Zee R., de Haan C. A. та iн.]. // J Virol. - 2003. - №77(16). - C. 8801-8811.

8. Tectonic conformational changes of a coronavirus spike glycoprotein promote membrane fusion. / Walls A. C., Tortorici M. A., Snijdera J. та ін.]. // Proc Natl Acad Sci U.S.A. - 2017. - №114(42). - C. 11157-11162.

9. A first case of meningitis/encephalitis associated with SARS-coronavirus-2. I Moriguchi T., Harii N., Goto J. та ін.]. // Int J Infect Dis. - 2020. - №94. - C. 55-58. https://www.doi.org/10.1016/j.ijid.2020.03.062

10. Role of the renin-angiotensin system in kidney development and programming of adult blood pressure. / Almeida L. F., Tofteng S. S., Madsen K. та iн.]. // Clin Sci (Lond). - 2020. - №134(6). - C. 641-656.

https://www.doi.org/10.1042/CS20190765

11. The anti-inflammatory potential of ACE2/angiotensin-(1-7)/Mas receptor axis: evidence from basic and clinical research. / Rodrigues Prestes T. R., Rocha N. P., Miranda A. S. та ін.]. // Curr Drug Targets. - 2017. - №18(11). - C.1301-1313.

https://www.doi.org/10.2174/1389450117666160727142401
12. Guillain-Barré syndrome associated with SARS-CoV-2 infection: causality or coincidence? / Zhao H., Shen D., Zhou H. та ін.]. // Lancet Neurol. - 2020. - №19(5). C. 383-384.

https://doi.org/10.1016/S1474-4422(20)30109-5

13. Coronavirus Infections in Central Nervous System and Respiratory Tract Show Distinct Features in Hospitalized Children / Yuanyuan Li, Haipeng Li, Ruyan Fan Ta ін.]. // Intervirology. - 2016. - №59. - C. 163-169.

https://doi.org/10.1159/000453066

14. Coronavirus disease 2019 and stroke: clinical manifestations and pathophysiological insights. / Divani A. A., Andalib S., Di Napoli M. та ін.]. // J Stroke Cerebrovasc Dis. -2020 . - №29(8). - C. 104941.

https://doi.org/10.1016/j.jstrokecerebrovasdis.2020.104941

15. Xinhua News Agency. 2020. Beijing hospital confirms nervous system infections by novel coronavirus.

16. Fitzgerald S. The spread of COVID-19: questions raised, some answered by neuroinfectious disease experts. / Fitzgerald S. // Neurology Today. March 12, 2020.

17. Psychiatric and neuropsychiatric syndromes and COVID-19 - Authors' reply. / Rogers J. P., Chesney E., Oliver D. [et al.]. // Lancet Psychiatry. - 2020. - №7(8). C. 664-665.

https://doi.org/10.1016/S2215-0366(20)30304-7

18. COVID-19-associated acute hemorrhagic necrotizing encephalopathy: imaging features. / Poyiadji N., Shahin G., Noujaim D. [et al.]. // Radiology. - 2020. №296(2). - E119-120.

https://doi.org/10.1148/radiol.2020201187

19. Stetka B. S. 2020. What neurologists can expect from COVID-19. Medscape.

20. Neurological and neuropsychiatric complications of COVID-19 in 153 patients: a UK-wide surveillance study. / Varatharaj A., Thomas N., Ellul M.A. [et al.]. // Lancet Psychiatry. - 2020. - № 7(10). - C. 875-882.

https://doi.org/10.1016/S2215-0366(20)30287-X

21. Influenza-like illness as a trigger for ischemic stroke. / Boehme A. K., Luna J., Kulick E. R. [et al.]. // Ann Clin TransI Neurol. - 2018. -№ 5(4). - C. 456-463. https://doi.org/10.1002/acn3.545

22. Mental morbidities and chronic fatigue in severe acute respiratory syndrome survivors: long-term follow-up. / Lam M. H., Wing Y. K., Yu M. W. [et al.]. // Arch Intern Med. - 2009. - №169(22). - C. 2142-2147.

https://doi.org/10.1001/archinternmed.2009.384 
23. Neurosciences study group and COVID SMIT PSL study group. / Delorme C., Paccoud 0., Kas S. [et al.]. // Eur J Neurol. - 2020. - №(12). - C. 2651-2657.

24. Neurological features of COVID-19 and their treatment: a review. / Orsucci D, Caldarazzo lenco E., Nocita G. [et al.]. // Drugs in Context. - 2020. - №9.

https://doi.org/10.7573/dic.2020-5-1

25. Mishchenko T., Mishchenko V. Неврологічні ускладнення у пацієнтів з COVID-19. / Mishchenko T., Mishchenko V. // Психіатрія, неврологія та медична психологія. - 2021. - №16. - С. 23-33.

https://doi.org/10.26565/2312-5675-2021-16-03

26. Venous and arterial thromboembolic complications in COVID-19 patients admitted to an academic hospital in Milan, Italy. / Lodigiani C, lapichino G, Carenzo L. [et al.] // Thromb Res. - 2020. - №191. - C. 9-14.

https://doi.org/10.1016/j.thromres.2020.04.024.

27. COVID-19 related neuroimaging findings: a signal of thromboembolic complications and a strong prognostic marker of poor patient outcome. / Jain R, Young $\mathrm{M}_{\text {, }}$ Dogra S, [et al.]. // J Neurol Sci. - 2020. - №414. - C. 116923.

https://doi.org/10.1016/j.jns.2020.116923.

28. COVID-19: how to protect yourself \& others [Електронний ресурс] // Centers for Disease Control and Prevention. - 2021. - Режим доступу до ресурсу: https:// www.cdc.gov/coronavirus/2019-ncov/prevent-getting-sick/prevention.html.

29. COVID-19: if you are sick or caring for someone [Електронний ресурс] // Centers for Disease Control and Prevention.. - 2020. - Режим доступу до ресурсу: https://www.cdc.gov/coronavirus/2019-ncov/if-you-are-sick/.

30. Remdesivir for the treatment of COVID-19 - final report. / Beigel J. H., Tomashek K. M., Dodd L. E., [et al.]. // N Engl J Med. - 2020. - №383(19). C. 1813-1826.

https://doi.org/10.1056/NEJMoa2007764

31. Remdesivir in adults with severe COVID-19: a randomised, double-blind, placebo-controlled, multicentre trial. / Wang Y., Zhang D., Du G., [et al.]. // Lancet. 2020. - №395(10236). - C. 1569-1578.

https://doi.org/10.1016/50140-6736(20)31022-9
32. Effect of remdesivir vs standard care on clinical status at 11 days in patients with moderate COVID-19: a randomized clinical trial. / Spinner C. D., Gottlieb R. L., Criner G. J., [et al.]. // JAMA. - 2020. - №324(11). C. 1048-1057.

https://doi.org/10.1001/jama.2020.16349

33. Remdesivir for 5 or 10 days in patients with severe COVID-19. / Goldman J. D. Lye D. C. B., Hui D. S., [et al.]. // N Engl J Med. - 2020 - №383(19). - C. 1827-1837.

https://doi.org/10.1056/NEJMoa2015301

34. Dexamethasone in hospitalized patients with COVID-19 - preliminary report. / RECOVERY Collaborative Group, Horby P, Lim WS, [et al.]. // N Engl J Med. 2020. - №384(8). - C. 693-704.

https://doi.org/10.1056/NEJMoa2021436

35. Methylprednisolone as adjunctive therapy for patients hospitalized with COVID-19 (Metcovid): a randomised, double-blind, Phase llb, placebo-controlled trial. / Jeronimo C. M. P., Farias M. E. L., Val F. F. A., [et al.]. // Clin Infect Dis. - 2020.

https://doi.org/10.1093/cid/ciaa1177

36. Effect of dexamethasone on days alive and ventilator-free in patients with moderate or severe acute respiratory distress syndrome and COVID-19: the CODEX randomized clinical trial. / Tomazini B. M., Maia I. S., Cavalcanti A. B., [et al.]. // JAMA. 2020. - №324(13). - C. 1307-1316.

https://doi.org/10.1001/jama.2020.17021

37. Effect of hydrocortisone on mortality and organ support in patients with severe COVID-19: the REMAP-CAP COVID-19 corticosteroid domain randomized clinical trial. / Angus D. C., Derde L., Al-Beidh F., [et al.]. // JAMA. - 2020 - №324(13). - C. 1317-1329. https://doi.org/10.1001/jama.2020.17022

38. Interleukin-6 receptor antagonists in critically ill patients with COVID-19. /

Gordon A. C., Mouncey P. R., Al-Beidh F., [et al.]. // N Engl J Med. - 2021. https://doi.org/10.1056/NEJMoa2100433

39. Tocilizumab in patients admitted to hospital with COVID-19 (RECOVERY): preliminary results of a randomised, controlled, open-label, platform trial. / Horby P. W., Pessoa-Amorim G., Peto L., [et al.]. // medRxiv. - 2021. https://doi.org/10.1101/2021.02.11.21249258

\section{REFERENCES}

1. Chen Y., Guo Y., Pan Y. [et al.]. Structure analysis of the receptor binding of 2019-nCoV. Biochem Biophys Res Commun. 2020. №. 525(1), pp. 135-140.

https://www.doi.org/10.1016/j.bbrc.2020.02.071

2. Zhou P., Yang X. L., Wang X. G. [et al.]. A pneumonia outbreak associated with a new coronavirus of probable bat origin. Nature. 2020. №. 579(7798), pp. 270-273.

https://www.doi.org/10.1038/s41586-020-2012-7

3. Coronaviridae Study Group of the International Committee on Taxonomy of Viruses 2020; Weiss and Navas-Martin 2005.

4. Rothan H. A., Byrareddy S. N. The epidemiology and pathogenesis of coronavirus disease (COVID-19) outbreak. J Autoimmun. 2020. №. 109, p. 102433.

https://www.doi.org/10.1016/j.jaut.2020.102433

5. Haidar A., Jourdi H., Haj Hassan Z. [et al.]. Neurological and neuropsychological changes associated with SARS-CoV-2 infection: new observation, new mechanisms. Review. The neuroscientist. 2021, p. 20.

https://www.doi.org/10.1177/1073858420984106

6. Coutard B., Valle C., de Lamballerie X. [et al.]. The spike glycoprotein of the new coronavirus 2019-nCoV contains a furin-like cleavage site absent in CoV of the same clade. Antiviral Research. 2020. №. 176, p. 104742.

https://www.doi.org/10.1016/j.antiviral.2020.104742

7. Bosch B. J., van der Zee R., de Haan C. A. [et al.]. The coronavirus spike protein is a class I virus fusion protein: structural and functional characterization of the fusion core complex. JVirol. 2003. №. 77(16), pp. 8801-8811.

8. Walls A. C., Tortorici M. A., Snijdera J. [et al.]. Tectonic conformational changes of a coronavirus spike glycoprotein promote membrane fusion. Proc Natl Acad Sci U.S.A. 2017. No. 114(42), pp. 11157-11162.

9. Moriguchi T., Harii N., Goto J. [et al.]. A first case of meningitis/encephalitis associated with SARS-coronavirus-2. Int J Infect Dis. 2020. №. 94, pp. 55-58.

https://www.doi.org/10.1016/j.ijid.2020.03.062
10. Almeida L. F., Tofteng S. S., Madsen K. [et al.]. Role of the renin-angiotensin system in kidney development and programming of adult blood pressure. Clin Sci (Lond). 2020. No. 134(6), pp. 641-656.

https://www.doi.org/10.1042/CS20190765

11. Rodrigues Prestes T. R., Rocha N. P., Miranda A. S. [et al.]. The antiinflammatory potential of ACE2/angiotensin-(1-7)/Mas receptor axis: evidence from basic and clinical research. Curr Drug Targets. 2017. No. 18(11), pp. 1301-1313.

https://www.doi.org/10.2174/1389450117666160727142401

12. Zhao H., Shen D., Zhou H. [et al.]. Guillain-Barré syndrome associated with SARS-CoV-2 infection: causality or coincidence? Lancet Neurol. 2020. №. 19(5), pp. 383-384.

https://doi.org/10.1016/S1474-4422(20)30109-5

13. Yuanyuan Li, Haipeng Li, Ruyan Fan [at el.]. Coronavirus Infections in Central Nervous System and Respiratory Tract Show Distinct Features in Hospitalized Children // Intervirology. 2016. No. 59, pp. 163-169.

https://doi.org/10.1159/000453066

14. Divani A. A., Andalib S., Di Napoli M. [et al.]. Coronavirus disease 2019 and stroke: clinical manifestations and pathophysiological insights. J Stroke Cerebrovasc Dis. 2020. No. 29(8), p. 104941.

https://doi.org/10.1016/j.jstrokecerebrovasdis.2020.104941

15. Xinhua News Agency. 2020. Beijing hospital confirms nervous system infections by novel coronavirus.

16. Fitzgerald S. 2020. The spread of COVID-19: questions raised, some answered by neuroinfectious disease experts. Neurology Today. 2020.

17. Rogers J. P., Chesney E., Oliver D. [et al.]. Psychiatric and neuropsychiatric syndromes and COVID-19 - Authors' reply. Lancet Psychiatry. 2020. No. 7(8), pp. 664-665.

https://doi.org/10.1016/S2215-0366(20)30304-7 
18. Poyiadji N., Shahin G., Noujaim D. [et al.]. COVID-19-associated acute hemorrhagic necrotizing encephalopathy: imaging features. Radiology. 2020. No. 296(2), pp. 119-120.

https://doi.org/10.1148/radiol.2020201187

19. Stetka B. S. 2020. What neurologists can expect from COVID-19. Medscape.

20. Varatharaj A., Thomas N., Ellul M.A. [et al.]. Neurological and neuropsychiatric complications of COVID-19 in 153 patients: a UK-wide surveillance study. Lancet Psychiatry. 2020. №. 7(10), pp. 875-882.

https://doi.org/10.1016/S2215-0366(20)30287-X

21. Boehme A. K., Luna J., Kulick E. R. [et al.]. Influenza-like illness as a trigger for ischemic stroke. Ann Clin TransI Neurol. 2018. No. 5(4), pp. 456-463.

https://doi.org/10.1002/acn3.545

22. Lam M. H., Wing Y. K., Yu M. W. [et al.]. Mental morbidities and chronic fatigue in severe acute respiratory syndrome survivors: long-term follow-up. Arch Intern Med 2009. No. 169(22), pp. 2142-2147.

https://doi.org/10.1001/archinternmed.2009.384

23. Delorme C., Paccoud 0., Kas S. [et al.]. Neurosciences study group and COVID SMIT PSL study group Eur J Neurol. 2020. №. (12), pp. 2651-2657.

24. Orsucci D, Caldarazzo lenco E., Nocita G. [et al.]. Neurological features of COVID-19 and their treatment: a review. Drugs in Contex.t 2020. No. 9.

https://doi.org/10.7573/dic.2020-5-1

25. Mishchenko T., Mishchenko V. Neurological complications in patient with COVID-19. Psychiatry, Neurology and Medical Psychology. 2021. No. 16, pp. 23-33. [In Ukr.].

https://doi.org/10.26565/2312-5675-2021-16-03

26. Lodigiani C, lapichino G, Carenzo L, et al. Venous and arterial thromboembolic complications in COVID-19 patients admitted to an academic hospital in Milan, Italy. Thromb Res. 2020. No. 191, pp. 9-14.

https://doi.org/10.1016/j.thromres.2020.04.024

27. Jain R, Young M, Dogra $S$, [et al.]. COVID-19 related neuroimaging findings: a signal of thromboembolic complications and a strong prognostic marker of poor patient outcome. J Neurol Sci. 2020. No. 414, p.116923

28. Centers for Disease Control and Prevention. COVID-19: how to protect yourself \& others. 2021. Available at: https://www.cdc.gov/coronavirus/2019-ncov/preventgetting-sick/prevention.html.

29. Centers for Disease Control and Prevention. COVID-19: if you are sick or caring for someone. 2020. Available at: https://www.cdc.gov/coronavirus/2019-ncov/if-youare-sick/.
30. Beigel J. H., Tomashek K. M., Dodd L. E., [et al.]. Remdesivir for the treatment of COVID-19 - final report. N Engl J Med. 2020. №. 383(19), pp. 1813-1826.

https://doi.org/10.1056/NEJMoa2007764

31. Wang Y., Zhang D., Du G., [et al.]. Remdesivir in adults with severe COVID-19: a randomised, double-blind, placebo-controlled, multicentre trial. Lancet. 2020. №. 395(10236), pp. 1569-1578.

https://doi.org/10.1016/S0140-6736(20)31022-9

32. Spinner C. D., Gottlieb R. L., Criner G. J., [et al.]. Effect of remdesivir vs standard care on clinical status at 11 days in patients with moderate COVID-19: a randomized clinical trial. JAMA. 2020. №. 324(11), pp. 1048-1057.

https://doi.org/10.1001/jama.2020.16349

33. Goldman J. D., Lye D. C. B., Hui D. S., [et al.]. Remdesivir for 5 or 10 days in patients with severe COVID-19. N Engl J Med. 2020. №. 383(19), pp. 1827-1837.

https://doi.org/10.1056/NEJMoa2015301

34. RECOVERY Collaborative Group, Horby P, Lim WS, [et al.]. Dexamethasone in hospitalized patients with COVID-19 - preliminary report. N Engl J Med. 2020. No. 384(8), pp. 693-704.

\section{https://doi.org/10.1056/NEJMoa2021436}

35. Jeronimo C. M. P., Farias M. E. L., Val F. F. A., [et al.]. Methylprednisolone as adjunctive therapy for patients hospitalized with COVID-19 (Metcovid): a randomised, double-blind, Phase Ilb, placebo-controlled trial. Clin Infect Dis. 2020.

https://doi.org/10.1093/cid/ciaa1177

36. Tomazini B. M., Maia I. S., Cavalcanti A. B., [et al.]. Effect of dexamethasone on days alive and ventilator-free in patients with moderate or severe acute respiratory distress syndrome and COVID-19: the CoDEX randomized clinical trial. JAMA. 2020. №. 324(13), pp. 1307-1316.

https://doi.org/10.1001/jama.2020.17021

37. Angus D. C., Derde L., Al-Beidh F., [et al.]. Effect of hydrocortisone on mortality and organ support in patients with severe COVID-19: the REMAP-CAP COVID-19 corticosteroid domain randomized clinical trial. JAMA. 2020. №. 324(13), pp. 1317-1329.

https://doi.org/10.1001/jama.2020.17022

38. Gordon A. C., Mouncey P. R., Al-Beidh F., [et al.]. Interleukin-6 receptor antagonists in critically ill patients with COVID-19. N Engl J Med. 2021.

https://doi.org/10.1056/NEJMoa2100433

39. Horby P. W., Pessoa-Amorim G., Peto L., [et al.]. Tocilizumab in patients admitted to hospital with COVID-19 (RECOVERY): preliminary results of a randomised, controlled, open-label, platform trial. medRxiv. 2021.

https://doi.org/10.1101/2021.02.11.21249258

\section{ОГЛЯД ПАТОГЕНЕЗУ, КЛІНІЧНИХ ПРОЯВІВ ТА ОСОБЛИВОСТЕЙ НЕРВОВО-ПСИХІЧНИХ ПОРУШЕНЬ, ВИКЛИКАНИХ COVID-19}

\section{Меркулова Ольга Юріївна}

*Харківський національний університет імені В. Н. Каразіна, майдан Свободи, 6, 61022, м. Харків, Україна

o.merkulova@karazin.ua

ORCID ID: 0000-0001-6880-0360

Haccp C. Caїд*

nassrsaid5@gmail.com

ORCID ID: 0000-0001-8553-4332

У статті представлені дані літератури з численними дослідженнями пацієнтів з COVID-19. Наявна інформація допомагає пояснити природу і будову вірусу, шляхи його проникнення та розповсюдження в організмі людини, взаємодію $з$ імунною, нервовою, ендокринною, судинною, м'язовою системами, а також патогенез, клініку, діагностику та лікування цього контингенту хворих. Через тропізму SARS-CoV-2 до людських клітин, специфічним для глікопротеїну S, цей вірус імітує рецептор людського ангіотензинперетворюючого ферменту 2 (АПФ-2), зливається з клітинами господаря і поширюеться в організмі. Ренін-ангіотензин- 
альдостеронової системи грає важливу роль в регуляції функцій кровоносних судин, серця, нирок. АПФ-2 впливає на запальні, фіброзні і імуномодулюючі механізми. Придушення цих захисних функцій через поширення SARS-COV-2 в організмі людини призводить до прогресування серцево-судинних, ниркових і легеневих захворювань. Деякі автори описують непряме проникнення вірусу в паренхіму головного мозку з інфікованими Т-лімфоцитами, яке зазвичай супроводжується запальними реакціями з підвищенням специфічних цитокінів, таких як інтерлейкіни (ІЛ) -6, ІЛ-8, фактор некрозу пухлини, моноцитарний хемотаксичний протеін-1.

Особливостями зв'язування вірусу з клітинами людини є наявність нейротропних властивостей і здатність змінювати проникність гематоенцефалічного бар'єра (ГЕБ). Інші автори відзначають, що вірус проникає через ГЕБ безпосередньо через нюхові нейрони і також структури, що оточують третій і четвертий шлуночки, і сприяє розвитку інфекції нервової системи. Він також може викликати внутрішньосудинне згортання і тромбоутворення, що призводить до різноманітних захворювань нервової системи. У зв'язку з цим важливим завданням неврологів $€$ подальше вивчення впливу вірусу COVID-19 на нервову систему і запобігання виникненню його ускладнень.

Ключові слова: COVID-19, SARS-COV-2, медіатори запалення, вірусні глікопротеїни, енцефаліт.

\section{ОБЗОР ПАТОГЕНЕЗА, КЛИНИЧЕСКИХ ПРОЯВЛЕНИЙ И ОСОБЕННОСТЕЙ НЕРВНО-ПСИХИЧЕСКИХ НАРУШЕНИЙ, ВЫЗВАННЫХ COVID-19}

\section{Меркулова \\ Ольга Юрьевна}

*Харьковский национальный университет имени В. Н. Каразина, площадь Свободы, 6, 61022, г. Харьков, Украина

o.merkulova@karazin.ua

ORCID ID: 0000-0001-6880-0360

nassrsaid5@gmail.com

ORCID ID: 0000-0001-8553-4332

В статье представлены данные литературы по многочисленным исследованиям пациентов с COVID-19. Имеющаяся информация помогает объяснить природу и строение вируса, пути проникновения и распространения в организме человека, взаимодействие его с иммунной, нервной, эндокринной, сосудистой, мышечной системами, а так же патогенез, клинику, диагностику и лечение этого контингента больных. Из-за тропизма SARS-CoV-2 к человеческим клеткам, специфичным для гликопротеина S, этот вирус имитирует рецептор человеческого ангиотензинпревращающего фермента 2 (АПФ-2), сливается с клетками хозяина и распространяется в организме. Ренин-ангиотензин-альдостероновая система играет важную роль в регуляции функций кровеносных сосудов, сердца, почек. АПФ-2 влияет на воспалительные, фиброзные и иммуномодулирующие механизмы. Подавление этих защитных функций из-за распространения SARS-CoV-2 в организме человека приводит к прогрессированию сердечно-сосудистых, почечных и легочных заболеваний. Некоторые авторы описывают косвенное проникновение вируса в паренхиму головного мозга с инфицированными Т-лимфоцитами, которое обычно сопровождается воспалительными реакциями с повышением специфических цитокинов, таких как интерлейкины (ИЛ) -6 , ИЛ-8, фактор некроза опухоли, моноцитарный хемотаксический протеин-1.

Особенностями связывания вируса с клетками человека являются наличие нейротропных свойств и способность изменять проницаемость гемато-энцефалического барьера (ГЭБ). Другие авторы отмечают, что вирус проникает через ГЭБ непосредственно через обонятельные нейроны и так же через структуры, окружающие третий и четвертый желудочки, что способствует развитию инфекций нервной системы. Он также может вызывать внутрисосудистое свертывание и тромбообразование, что приводит к различным заболеваниям нервной системы. В связи с этим важной задачей неврологов является дальнейшее изучение влияния вируса COVID-19 на нервную систему и предотвращение возникновения его осложнений.

Ключевые слова: COVID-19, SARS-COV-2, медиаторы воспаления, вирусные гликопротеины, энцефалит. 